\title{
ASN, OTDA, POLITIK PILKADA SERENTAK DAN KORUPSI DI INDONESIA
}

\author{
Herdi Salioso
}

\begin{abstract}
Corruption is not a new term in Indonesia, only recently started realizing ingrained and entrenched. The problem of corruption becomes increasingly macro and massive when regional autonomy (OTDA) and coloring Election Political Democratization in Indonesia. The phenomenon of corruption which delivers Indonesia as the most corrupt country in the world, increasingly gives the impression assured in order to prevent and overcome, when the instrument and the substance of the existing law is not able to give effect deterrence for perpetrators and potential perpetrators.
\end{abstract}

Key words: Culture of Corruption

\begin{abstract}
ABSTRAK
Korupsi bukan istilah baru di Indonesia, hanya saja baru disadari mulai mendarah daging dan membudaya. Persoalan korupsi menjadi semakin makro dan massif tatkala Otda dan Politik Pilkada mewarnai Demokratisasi di indonesia. Fenomena korupsi yang menghantarkan indonesia sebagai negara terkorup di dunia ini, semakin tak memberikan kesan meyakinkan dalam rangka pencegahan dan penanggulangannya, manakala instrumen dan substansi hukum yang ada tidak mampu memberikan efek penggentarjeraan bagi pelaku dan calon pelaku.
\end{abstract}

Kata kunci:Budaya Korupsi

\section{PENDAHULUAN}

Sudah hampir dua dasawarsa lebih, perhatian Bangsa Indonesia terfokus pada pembicaraan Otonomi Daerah yang didalamnya berurutan Reformasi Birokrasi yang berujung pada keluarnya Undang-undang tentang ASN dan PILKADA Serentak, dimana oleh sebahagian besar orang menganggap para pelaku utamanya adalah PNS atau ASN. Otonomi daerah memberikan kewenangan yang lebih kepada daerah untuk menentukan arah dan tujuan pembangunan daerahnya dengan rancangan sendiri.

PILKADA Serentak memberikan hak yang lebih besar kepada masyarakat secara langsung menentukan Kepala Daerahnya sendiri. Reformasi Birokrasi berusaha menyempurnakan peran dan fungsi ASN atau PNS sebagai pelayan masyarakat. Kesemuanya mengarah Kepada perbaikan penyempurnaan agar tercipta tatanan pemerintahan yang lebih baik. Oleh karena itu hampir semua lapisan masayarakat berkeinginan akan adanya suatu perubahan yang menyeluruh dan sempurna di Indonesia. Namun disebalik keinginan luhur dalam hal perubahan tersebut, hampir semuanya belum berjalan dengan baik. Hampir disemua daerah terjadi tindak penipuan mulai dari penyelenggara, pelaku dan masyarakat serta partai politik seakan berlomba-lomba melakukan kecurangankecurangan yang merusak tatanan dan sendisendi demokrasi yang diagung-agungkan terutama pada permulaan era reformasi yang melahirkan otonomi daerah tersebut. Kecurangan-kecurangan yang begitu banyak harus dibayar dengan hight cost yang yang menguras kekayaan negara yang seharusnya dipergunakan untuk pembangunan yang mensejahterakan masyarakat. Namun yang terjadi adalah pemborosan dan pengurasan kekayaan tersebut untuk kepentingan segelintir orang dan kepentingan kelompok kepentingan yang kita kenal dengan Partai Politik dimana pada gilirannya muncul dan paling menonjol yang terjadi dari hal-hal tersebut bermuara kepada tindak pidana yang kita kenal dengan nama korupsi.Menurut Kamus Bahasa Indonesia (Poerwadarminta;1991), Pegawai berarti orang yang bekerja pada pemerintah, perusahaan dan sebagainya. Manakala menurut Wijaya (2002) pegawai mengandung penertian : a. Menjadi anggota suatu kerjasama (organisasi) dengan maksud memperoleh balas jasa/imbalan kompensasi atas jasa yang telah diberikan, b. Berada dalam sistem kerja yang sifatnya lugas/pamrih. c. Berkedudukan sebagai penerima kerja dan berhadapan dengan pihak pemberi kerja. d. Kedudukan seabgai penerima 
kerja diperoleh setelah melalui proses penerimaan. e. Dan akan menghadapi masa pemberhentian (pemutusan hubungan kerja antara pemberi kerja dengan penerima kerja).

Dalam pasal 1 ayat (1) UU Nomor : 43 Tahun 1999 tentang perubahan atas UU Nomor : 8 Tahun 1974 tentang Pokok-Pokok Kepegawaian, disebutkan bahwa Pegawai Negeri adalah Setiap Warga Negara RI yang telah memenuhi syarat yang ditentukan, diangkat oleh pejabat yang berwenang dan diserahi tugas dalam suatu jabatan negeri, atau diserahi tugas negara lainnya dan digaji berdasarkan peraturan perundang-undangan yang berlaku. Dari definisi diatas terdapat paling tidak empat unsur yang harus dipenuhi oleh seseorang agar dapat disebut sebagai Pegawai Negeri Sipil yaitu :

1. Memenuhi syarat yang ditentukan oleh peraturan perundang-undangan yang berlaku.

2. Diangkat oleh pejabat yang berwenang.

3. Diserahi tugas dalam jabatan negeri atau jabatan negara lainnya.

4. Digaji berdasarkan peraturan perundangundangan yang berlaku.

Berdasarkan pasal 3 ayat (1) UU Nomor : 43 Tahun 1999 dijelaskan bahwa PNS berkedudukan sebatgai unsur aparatur negara yang bertugas untuk memberikan pelayanan kepada masyarakat secara profesional, jujur, adil dan merata dalam penyelenggaraan tugas negara, pemerintahan dan pembangunan. Dalam kesehariannya, terutama dalam era otonomi daerah, PNS tidak dikecualikan dalam proses PILKADA Serentak 2015 dan berhak ikut serta dalam PILKADA Serentak tersebut. Semua itu dapat dilakukan dengan memenuhi ketentuan peraturan perundang-undangan yang berlaku sebagaimana diatur dalam Undang-Undang 43 Tahun 1999 tersebut.

\section{OTONOMI DAERAH.}

Dalam Undang-Undang Nomor : 32 Tahun 2004, pada pasal 1 ayat (5) disebutkan bahwa otonomi daerah adalah Hak, wewenang, dan kewajiban daerah otonom untuk mengatur dan mengurus sendiri urusan pemerintahan dan kepentingan masyarakat setempat sesuai dengan peraturan perundang-undangan. Suparmoko (2002), mengartikan otonomi daerah merupakan kewenangan daerah otonom untuk mengatur dan mengurus kepentingan masyarakat setempat menurut prakarsa sendiri berdasarkan aspirasi masyarakat.
Otonomi daerah diarahkan untuk memacu pemerataan pembangunan dan hasil-hasilnya, meningkatkan kesejahteraan rakyat, menggalakkan prakarsa dan peranserta aktif masyarakat secara nyata, dinamis dan bertanggung-jawab sehingga memperkuat persatuan dan kesatuan bangsa, mengurangi beban pemerintah pusat dan campur tangan di daerah yang akan memberikan peluang untuk koordinasi tingkat lokal.

Lebih jauh Mardiasmo mengatakan bahwa otonomi daerah merupakan upaya untuk meningkatkan pelayanan publik (public service) dan memajukan perekonomian daerah, dimana didalamnya terkandung tiga misi utama yaitu :

1. Meningkatkan kualitas dan kuantitas pelayanan publik dan kesejahteraan masyarakat.

2. Menciptakan efisiensi dan efektivitas pengelolaan sumber daya daerah.

3. Memberdayakan dan menciptakan ruang bagi masyarakat (publik) untuk berpartisipasi dalam proses pembangunan.

\section{POLITIK PILKADA SERENTAK}

Pemilihan Kepala Daerah Serentak (PILKADA atau Pemilukada) yang akan dilaksanakan serentak pada Akhir Tahun 2015 ini merupakan salah satu sarana demokrasi yang tercantum dalam Undang-Undang Otonomi Daerah. Merupakan Pesta demokrasi yang merupakan perwujudan tatanan kehidupan negara dan masyarakat yang berkedaulatan rakyat, pemerintahan dari dan untuk rakyat. Melalui Pemilukada, setidaknya dapat dicapai tiga hal diantaranya :

1. Dapat menguji hak-hak politik rakyat secara masif dan serempak.

2. Melalui Pemilukada kita berharap dapat memilih atau merekruitmen pemimpin secara adil, terbuka dan kompetitif.

3. Terjadi proses penggiliran pimpinan secara damai.

\section{KORUPSI DISEKITAR KITA}

Dalam kamus bahasa Indonesia $(2001 ; 597)$ dikatakan korupsi berarti penyelewengan atau penyalahgunaan uang negara (perusahaan) untuk keuntungan pribadi atau orang lain. Dalam arti yang lebih luas korupsi dapat juga diartikan sebagai menyelewengkan atau 
menggelapkan (uang dan sebagainya). Sebenarnya korupsi berasal dari bahasa latin yaitu corruptio yang berarti penyuapan; corruptore yang berarti merusak. Gejala dimana para pejabat, badan-badan negara menyalahgunakan wewenang dengan terjadinya penyuapan, pemalsuan serta ketidak-beresan lainnya (Evi Hartanti, 2005; 8).

Secara harfiah, menurut S.Wojowasito-WJS, Poerwadarma (1976), korupsi dapat berupa kejahatan, kebusukan, dapat disuap, tidak bermoral, kebejatan dan ketidak-jujuran. Lebih jauh menurut beliau, korupsi merupakan perbuatan buruk seperti penggelapan uang, penerimaan uang sogok, dan sebagainya.

Menurut Muhammad Ali (1980), kata korupsi berasal dari kata korup yaitu busuk; suka menerima uang suap, uang sogok, memakai kekuasaan untuk kepentingan sendiri dan sebagainya. Lalu korupsi diartikan sebagai perbuatan busuk seperti penggelapan uang, penerimaan uang sogok dan sebagainya. Dan orang yang melakukannya disebut koruptor. Korupsi merupakan sesuatu yang busuk, jahat dan merusak dan menyangkut segi-segi moral, sifat dan keadaan yang busuk, jabtan dalam instansi atau aparatur pemerintah, penyelewengan kekuasaan dalam jabtan karena pemberian, faktor ekonomi dan politik serta penempatan keluarga atau golongan ke dalam kedinasan dibawah kekuasaan jabatannya.

Oleh karena itu, secara harfiah, korupsi memiliki arti yang sangat luas yaitu merupakan penyelewengan atau penggelapan (uang negara atau perusahaan dan sebagainya) untuk kepentingan pribadi dan orang lain serta korupsi merupakan busuk, rusak, suka memakai barang atau uang yang dipercayakan kepadanya, dapat disogok (melalui kekuasaannya untuk kepentingan pribadi.

\section{KORUPSI BUKAN BARANG BARU}

Hari-hari belakangan ini, hampir seluruh media massa, menyiarkan berita tentang korupsi. Tiap detik, menit, jam dan hari serta minggu, bulan dan bahkan tahun, cerita tentang korupsi marak diberitakan dari yang berskala kecil sampai besar dan bahkan mega korupsipun tak ketinggalan menghiasi halaman utama dan berita utama surat kabar dan televisi. Mulai dari Lumpur Lapindo, Bank Century, pajak, Haji, Daging Sapi, Beras, Pelabuhan atau sebut saja Gayus Tambunan, Enji, Nazaruddin, Andi Malrangeng, Partai Demokrat, PKS dengan segudang kadernya, pengusaha semisal Ahmad
Fatanah dan jibunan Kepala Daerah, Penyelenggara Birokrasi sampai kepada akar rumput yang paling bawah. Partai Persatuan Pembangunan dengan Surya Dharma Ali, sampai kembali ke Kader Demokrat Sutan Bhatoegana yang sering nyentrik di depan layar kaca. Semuanya terlibat masalah korupsi. Sungguh mengherankan, di negara yang menyatakan beragama (ada 5 agama besar yang dipercayai), tingkat kejahatan korupsinya malah begitu besar. Bahkan Indonesia menjadi salah satu negara terkorup di dunia, dimana sudah tak dapat dihitung lagi berapa besarnya uang negara yang masih miskin ini lenyap entah kemana rimbanya yang kebanyakan terjadi setelah era otonomi daerah itu dijadikan jargon perubahan di negeri ini.

Di dalam sosiologi dipelajari bagaimana masyarakat mempengaruhi fenomena uang dan keuangan serta sebaliknya bagaimana fenomena uang dan keuangan mempengaruhi masyarakat. Fenomena uang dan keuangan tidak hanya berskala mikro seperti bagaimana individu atau antar individu berinteraksi melakukan aktivitas yang berhubungan dengan uang dan keuangan seperti interpretasi sosial budaya terhadap uang, sikap dan pemahaman individu dan antar individu dalam mencari uang, atau usaha sosial dan budaya dari individu untuk menghindari jerat utang. Selain bersifat mikro uang dan keuangan dapat juga berskala makro seperti bagaimana konstruksi sosial budaya dan politik terhadap korupsi dan uang haram (Damsar, $1995 ; 155)$.

Kalau kita lebih mencermati lagi fenomena saat ini dimana korupsi itu bukan lagi menjadi barang langka yang sulit untuk ditemukan, tetapi ianya sudah menjadi barang baru yang mendarah daging. Individu, kelompok dan golongan tidak lagi merasa kalau perbuatan "korupsi" itu sesuatu yang buruk. Ianya, hari ini menjadi sesuatu yang sudah lazim dan banyak pihak tidak takut terhadap sanksi yang bakal dijatuhkan. Malah ada yang berpendapat bahwa lebih baik melakukan "korupsi" dan mendapatkan imbalan yang besar daripada mengabdi dengan kejujuran tetapi hidup dalam kemiskinan. Memang ada beberapa penjahat korupsi yang dikenakan sanksi berupa hukuman dan penyitaan harta kekayaannya, namun tidak sedikit koruptor terutama kelas atas dengan omzet milyaran dan trilyunan yang masih melenggang, santai dan tak tersentuh oleh hukum yang mengatur Negara ini. Sebahagian besar lenyap bak ditelan bumi ketika mereka dengan mudahnya keluar negeri dengan 
berbagai alasan terutama berobat (sakit) dan lain sebagainya dan akhirnya tidak pernah kembali lagi untukmempertanggung-jawabkan perbuatannya.

Ada juga korupsi yang jelas-jelas merugikan banyak keuangan Negara yang jumlahnya trilyunan rupiah, tetapi siapa pelakunya tidak jelas atau dikaburkan, walaupun secara pasti masyarakat sudah tahu siapa dalangnya. Contohnya kasus Bank Century dan masih banyak kasus-kasus lainnya yang mewabah, bukan hanya pada tingkat pusat (departemen, BUMN dan partai politik) tetapi juga pada tingkatan Provinsi, Kabupaten, Kota, Kecamatan dan bahkan sampai ke tingkat RW dan RT. Seolah-oleh korupsi sudah menjadi budaya dan makruh hukumnya.

Membincangkan korupsi, bukan sesuatu yang baru. Korupsi sudah ada sejak peradaban manusia belum sempurna. Ketika interaksi sosial belum seperti sekarang ini. Ingat ketika generasi pertama dari Nabi Adam AS, yaitu Kabil dan Habil yang diperintahkan Allah SWT untuk memberikan sedekahnya. Ketika Habil selaku peternak mempersembahkan hasil peternakannya yang paling bagus untuk dipersembahkan kepada Tuhannya dan Kabil selaku petani menyediakan buah-buahan yang kurang baik dan sebahagiannya sudah busuk, maka dari kejadian ini terlihat bahwa korupsi itu sudah muncul pada saat tersebut (Damsar, 1995; 2) Rupanya, aktivitas korupsi merupakan sesuatu yang menyenangkan, sehingga sampai hari ini upaya yang telah gencar dilakukan, bukannya menambah penurunan minat orang untuk berkorupsi tetapi malah sebaliknya dan yang lebih mencengangkan lagi, mereka yang berteriak-teriak "berantas korupsi", enyahkan korupsi" dan lain sebagainya, rupanya setali tiga uang, malah melakukan tindak pidana korupsi dalam jumlah yang tidak sedikit.

Banyak orang bilang, baik masyarakat umum, para ahli ilmu pengetahuan umum ataupun para pakar hukum, ahli ilmu sosial dan lain sebagainya sepakat mengatakan bahwa korupsi merupakan suatu tindakan melawan hukum dan merusak sendi-sendi moral bangsa dan menghambat pembangunan. Proses pembangunan sebenarnya merupakan suatu kegiatan yang dilakukan dalam kehidupan masyarakat yang menimbulkan kemajuan. Selain itu, proses pembangunan juga mengakibatkan perubahan kondisi sosial masyarakat yang memiliki dampat sosial negatif, terutama menyangkut masalah peningkatan tindak pidana yang sangat meresahkan masyarakat. KH. Zainuddin MZ, dalam suatu ceramahnya menyatakan bahwa korupsi lebih berbahaya dari pembunuhan. Pembunuhan dilakukan secara langsung dan mangsanya akan mati seketika. Berbeda dengan korupsi, ia dilakukan secara berangsur atau langsung dimana korbannya mati secara perlahan-lahan. Dilemahkan, lalu dilemahkan lagi dan akhirnya setelah menderita yang cukup panjang baru mati. Sungguh kejam.

\section{NEGARA DAN UPAYA PENEGAKAN HUKUM}

Dalam ilmu sosial dan politik, banyak sekali definisi yang diberikan oleh para ahli tentang negara, baik oleh para pakar yang berasal dari negara-negara eropa maupun dari para pakar Indonesia sendiri. George Jellinek (lihat AA. Said Gatara, 2007) dengan teori Dua Segi (Zweisten Theorie) yang menyatakan bahwa negara merupakan organisasi tertinggi dari bangunan hukum disatu sisi dan bangunan masyarakat disisi yang lain. Dari definísi ini dapatlah dilihat negara dari dua sudut pandang yang berbeda yaitu dari sudut pandang yuridis; dimana negara sebagai bangunanhukum dan sudut pandang yang lain yaitu sosiologis yaitu negara sebagai bangunan atau kenyataan masyarakat.

Manakala Harold J. Laski (1947) menyatakan ...the state is a society which is integrated bya posessing a coercive authority legally supreme over any individual or group which is part of the society. A society is a groups of human being living together and working together for the satisfaction of their mutual wants. Such asociety is a state when the way of life to which both individuals and associations must conform is defined bya a coercive authority binding upon the all.

Dari pernyataan tersebut dapatlah dikatakan bahwa Negara merupakan suatu masyarakat yang diintegrasikan karena memiliki wewenang yang bersifat memaksa dan secara sah lebih agung daripada individu atau kelompok yang merupakan bagian dari masyarakat berkenaan. Masyarakat adalah suatu kelompok manusia yang hidup dan bekerjasama untuk tercapainya keinginan mereka bersama. Masyarakat merupakan Negara kalau cara hidup yang harus ditaati, baik oleh individu maupun asosiasi ditentukan oleh wewenang yang bersifat memaksa atau mengikat. 
Lebih lanjut Negara merupakan suatu daerah territorial yang rakyatnya diperintah (governed) oleh sejumlah pejabat yang berhasil menuntut warga negaranya ketaatan peraturan perundangundangannya melalui penguasaan (controll) monopolistis dari kekuasaan yang sah (Miriam Budiarjo, 2004).Di Negara Indonesia, ditegaskan dalam Undang-Undang Dasar 1945 ditegaskan bahwa Negara Indonesia adalah negara berdasarkan hukum (rechtstaat), tidak berdasarkan atas kekuasaan belaka (machstaat). Kenyataan ini menunjukkan bahwa Negara Republik Indonesia adalah Negara Hukum yang demokratis berdasarkan Pancasila dan Undang_undang Dasar 1945, menjunjung tinggi Hak Asasi Manusia dan menjamin semua warga negara sama kedudukannya dalam hukum dan pemerintahan serta wajib menjunjung hukum dan pemerintahan dengan tidak ada pengecualiannya.

Oleh karena itu, hukum menetapkan apa yang harus dilakukan dan atau apa yang boleh dilakukan serta yang menjadi larangan. Sasaran hukum yang hendak dituju bukan saja orang yang nyata-nyata berbuat melawan hukum, melainkan juga perbuatan hukum yang mungkin akan terjadi dan kepada alat perlengkapan Negara untuk bertindak menurut hukum. Sistem bekerjanya hukum yang demikian itu merupakan salah satu bentuk penegakan hukum.

\section{UNDANG-UNDANG NOMOR : 31/1999 DAN UNDANG-UNDANG NOMOR : 20/2001}

Dalam perkembangan sejarah, Indonesia mengalami pasang surut dalah hal tindak kejahatan, terutama korupsi. Langkah-langkah pembentukan hukum dalam menghadapi tindak kerjahatan korupsi terus dilakukan. Sebenarnya orang mengenal korupsi sebagai salah satu istilah yuridis baru digunakan pada tahun 1957 oleh Penguasa Militer yang berlaku di daerah kekuasaan Angkatan Darat (Peraturan Militer Nomor : PRT/PM/06/1957) dimana didalamnya diatur mengenai tindak pidana korupsi sebagai berikut :

1. Masa Peraturan Militer, yang terdiri atas :

2. Masa Undang-Undang Nomor : 24/PRP/Tahun 1960 tentang Pengusutan, Penuntutan dan Pemeriksaan Tindak Pidana Korupsi yang merupakan Peraturan Pemerintah Pengganti Undang-Undang Nomor : 24 Tahun 1960 yang tertera dalam Undang-Undang Nomor : 1 Tahun 1961.

3. Undang-Undang Nomor : 3 Tahun 1971 tentang Pemberantasan Tindak Pidana Korupsi.

4. Masa Undang-Undang Nomor : 31 Tahun 1999 tentang Pemberantasan Tindak Pidana Korupsi yang kemudian diubah menjadi Undang-undang Nomor : 20 Tahun 2001 tentang Perubahan Atas Undang-Undang Nomor : 31 Tahun 1999 tentang Pemberantasan Tindak Pidana Korupsi yang selanjutnya pada tanggal 27 Desember 2002 dikeluarkan UndangUndang Nomor : 30 Tahun 2002 tentang Komisi Pemberantasan Tindak Pidana Korupsi.

Undang-undang diluar Kitab UndangUndang Hukum Pidana (KUHP) ini dikeluarkan dengan landasan hukum pada pasal 103 KUHP yang menyatakan bahwa Ketentuan-ketentuan dalam Bab I sampai Bab VIII buku ini juga berlaku bagi perbuatan-perbuatan yang oleh ketentuan perundang-undangan lainnya diancam dengan pidana, kecuali jika oleh undang-undang ditentukan lain. Hal ini dapat diartikan sebagai suatu bentuk aturan khusus telah mengesampingkan aturan umum (Lex Specialis Derogat Legi Generali). Dengan kata lain pasal 103 KUHP ini memungkinkan suatu ketentuan perundang-undangan di luar KUHP untuk mengesampingkan ketentuan-ketentuan yang telah diatur dalam KUHP. Kemudian dalam Kitab Undang-Undang Hukum Pidana (KUHP) sebenarnya terdapat ketentuanketentuan yang mengancam dengan pidana orang yang melakukan delik jabatan, pada khususnya delik-delik yang dilakukan oleh pejabat (ambtenaar) yang terkait dengan korupsi.

\section{SULITNYA MENILAI KEJAHATAN KORUPSI YANG ADIL}

Sulitnya menilai kejahatan korupsi yang adil sangat dirasakan, bukan hanya kepada pelaku tindak pidana korupsi itu sendiri tetapi juga para pakar dan masyarakat awam yang seringkali kebingungan dengan putusan-putusan yang dijatuhkan oleh majelis hakim terhadap pelaku kejahatan korupsi. Memang sudah ada upaya pemerintah untuk memerangi tindak pidana korupsi sampai ke akar-akarnya, namun juga ditemui berbagai persoalan lain yang muncul ketika suatu persoalan korupsi itu diangkat ke permukaan. Komisi Pemberantasan Korupsi (KPK) merupakan salah satu lembaga 
pemerintah yang menangani perkara tindak pidana korupsi belum berfungsi secara efektif dan efisien dalam pemberantasan tindak pidana korupsi di Indonesia. Harus kita akui bahwa tindak pidana korupsi di Indonesia sudah meluas dalam masyarakat dimana tingkat perkembangannya dari tahun ke tahun semakin meningkat baik dari segi jumlah kasus yang terjadi dan besarnya kerugian negara yang harus ditanggung disamping semakin meningkatnya kualitas tindak pidana yang dilakukan secara sistematis yang telah memasuki wilayah yang lebih luas yaitu mencakup hampir semua aspek kehidupan masyarakat.

Penegakan hukum dalam rangka memberantas tindak pidana korupsi yang dilakukan secara konvensional, ternyata mengalami berbagai hambatan sehingga perlu peningkatan dalam metode dalam penegakan hukum melalui pembentukan badan yang kuat (super body) yang memiliki kewenangan yang luas, independent serta bebas dari kekuasaan pihak manapun dan harus dilakukan secara optimal, instensif, efektif, professional serta berkesinambungan. KPK dalam hal ini telah memiliki landasan kebijakan yang kuat dalam upaya memerangi tindak pidana korupsi dimana semua kebijakan tersebut tertuang dalam dalam ketentuan pasal 43 Undang-Undang Nomor : 31 Tahun 1999 tentang Pemberantasan Tindak Pidana Korupsi yang telah disempurnakan melalui Undang-Undang Nomor : 20 Tahun 2001 dimana kewenangan KPK untuk melakukan koordinasi dan supervisi, termasuk melakukan penyelidikan, penyidikan dan penuntutan semakin luas.

Namun demikian, walaupun tugas, wewenang dan kewajiban KPK sudah semakin luas dan jelas, masih saja ditemui berbagai hal yang tidak sejalan dengan pemikiran masyarakat terutama dalam hal penuntutan yang tidak pernah sama dari suatu kasus yang berbeda. Beberapa contoh kasus korupsi yang menyeret begitu banyak tokoh politik, birokrat telah memberikan gambaran tidak jelasnya pola penerapan sanksi yang diberikan kepada para pelaku tindak pidana korupsi. Ada banyakkasus besar yang menyeret petinggi negara yang merugikan Negara ratusan milyar bahkan lebih tetapi hanya diberikan ganjaran yang ringan dan bahkan tidak jarang pesakitan menerima vonis bebas dari semua tuduhan walaupun barang bukti tindak kejahatannya jelas. Kasus seperti ini seakan-akan menjadikan hokum hanya tajam kepada pelaku kelas teri dan tumpul kepada pelaku kelas kakap.
Kita contohkan kasus Akbar Tanjung yang menerima 2 buah cek senilai masing-masing 10 milyar rupiah dari dana Bulog untuk penyaluran sembako seluruhnya sebesar 40 milyar rupiah. Dalam kenyataannya Akbar Tanjung mengaku menerima sejumlah dana tersebut, tetapi kemudian diserahkan kepada yayasan yang ia sendiri lupa namanya, walaupun akhirnya Akbar Tanjung meralat pernyataannya tersebut dan membantah dengan mengatakan tidak menerima uang tersebut, tetapi hanya melihat Rusnandar menyerahkan cek senilai nominal tersebutkepada yayasan. JPU yang diketuai oleh Fachmi, SH menuntut Akbar Tanjung dengan hukuman empat tahun penjara dan Majelis Hakim PN Jakarta Pusat akhirnya menjatuhkan vonis tiga tahun kepada Akbar Tanjung.

Lain Akbar, lain lagi Syahril Sabirin, terdakwa dalam kasus Bank Bali yang dinyatakan tidak bersalah dan bebas berdasarkan keputusan Pengadilan Tinggi Jakarta dalam keputusannya tanggal 12 Agustus 2002, walaupun sebelumnya Pengadilan Tinggi Jakarta Pusat telah menjatuhkan vonis 3 tahun dan denda 15 juta rupiah subsider tiga bulan penjara melalui keputusan tanggal 13 Maret 2002. Syahril mempunyai peran besar dalam kasus Bank Bali, ketika beliau menjabat sebagai Gubernur Bank Indonesia yang memerintahkan pembayaran klaim oleh Bank Bali terhadap Bank BDNI sebesar 904 milyar rupiah lebih.

Dalam kasus korupsi yang lain, Probo Sutedjo, Direktur Utama PT. Menara Hutan Buaya dinyatakan tidak memenuhi kewajibannya melakukan penanaman kembali atas lahan Proyek Hutan Tanaman Industri (HTI) di Kalimantan Selatan sebagaimana perjanjian. Proyek HTI tersebut dibiayai Negara melalui dana Reboisasi sebesar 100,9 milyar rupiah untuk menamam kembali 71.000 hektar. Namun berdasarkan survey Bakorsurtanal, luas lahan yang ditanam hanya 29,675 hektar. Probo Sutedjo divonis penjara selama 4 tahun dan denda sebesar 30 juta rupiah subsider tiga bulan kurungan.

Putusan Hakim PN Jakarta Selatan kepada Rahardi Ramelan, Mantan Meneteri Perindustrian Perdagangan /Kepala Bulog yang dianggap terbukti bersalam kasus penyalahgunaan dana non budgeter Bulog senilai 62,9 milyar rupiah dengan denda sebesar 50 juta rupiah subsider 3 bulan dan mengganti dana yang dikeluarkan sebesar 400 juta rupiah dan diharuskan melunasi biaya perkara sebesar 
7.500 rupiah, menjadi salah satu vonis yang kontroversi dalam kasus tindak pidana korupsi. Mari kita bandingkan dengan vonis majelis Hakim Pengadilan Negeri Kota Dumai terhadap Mustar Effendi, Mantan Sekretaris Daerah Kota Dumai terkait perkara penyelewengan APBD Kota Dumai sebesar satu milyar rupiah dimana dana sebesar tersebut merupakan dana penyertaan modal pemerintah Kota Dumai dalam rangka pembangunan PDAM Kota Dumai bekerja sama dengan pihak ketiga. Dari penyelidikan pihak kejaksaan terindikasi beliau menerima kucuran dana sebesar 100 juta rupiah dari proses kerjasama tersebut. Tetapi apa lacur, pengadilan negeri Kota Dumai menjatuhkan sanksi hukuman selama 5 tahun kepada Mustar Effendi. Inilah suatu gambaran bahwa kita belum siap untuk menjadi penyelenggara negara yang bersih, bagaimana ingin membersihkan negara dari korupsi?

\section{PENUTUP}

Otonomi daerah memberikan kewenangan yang lebih kepada daerah untuk menentukan arah dan tujuan pembangunan daerahnya dengan rancangan sendiri. PILKADA SERENTAK memberikan hak yang lebih besar kepada masyarakat secara langsung menentukan Kepala Daerahnya sendiri. Reformasi Birokrasi berusaha menyempurnakan peran dan fungsi PNS sebagai pelayan masyarakat. Kesemuanya mengarah kepada perbaikan penyempurnaan agar tercipta tatanan pemerintahan yang lebih baik. Oleh karena itu, hampir semua lapisan masayarakat kita berkeinginan akan adanya suatu perubahan yang menyeluruh dan sempurna di Indonesia.

Namun disebalik keinginan luhur dalam hal perubahan tersebut, hampir semuanya belum berjalan dengan baik. Hampir disemua daerah terjadi tindak penipuan mulai dari penyelenggara, pelaku dan masyarakat serta partai politik seakan berlomba-lomba melakukan kecurangan-kecurangan yang merusak tatanan dan sendi-sendi demokrasi yang diagung-agungkan terutama pada permulaan era reformasi yang melahirkan otonomi daerah tersebut. yang bermuara kepada tindak pidana yang kita kenal dengan nama korupsi. Fenomena uang dan keuangan tidak hanya berskala mikro seperti bagaimana individu atau antar individu berinteraksi melakukan aktivitas yang berhubungan dengan uang dan keuangan sebagaimana interpretasi sosial budaya terhadap uang, yang menjalar pada proses Pemilukada yang hampir disemua daerah.

\section{SUMBER REFRENSI}

AA. Said Gatara, Sosiologi Politik; Konsep Dinamika Perkembangan Kajian, Penerbit Pustaka Setia, Bandung, 2007.

Alatas, Syed Hussein, Sosiologi Korupsi, Penerbit LP2ES, Jakarta, 1983.

Arief, Barda Nawawi dan Muladi, Bunga Rampai Korupsi, Penerbit Alumni, Bandung, 1992.

Budiarjo, Miriam, Dasar-dasar Ilmu Politik, Penerbit Gramedia Pustaka Utama, Jakarta, 2004.

Damsar, Sosiologi Ekonomi, Penerbit PT. Raja Grafindo Persada, Jakarta, 2002.

Hartanti, Evi, Tindak Pidana Korupsi, Edisi Kedua, Penerbit Sinar Grafika, Semarang, 2005.

Lanski, Harold, The State in Theory and Practice, The Viking Press, New York, 1947.

Lopa, Baharuddin, Kejahatan Korupsi dan Penegakan Hukum.

Marpaung, Leden, Tindak Pidana Korupsi, Penerbit Djambatan, Jakarta, 2001.

Mulyadi, Lilik, Tindak Pidana Korupsi, Penerbit Citra Aditya Bakti, Bandung, 2000.

Saleh K. Wantjik, Tidak Pidana Korupsi dan Suap, Penerbit Ghalia Indonesia, Jakarta 